Vietnam Academy of Science and Technology
Vietnam Journal of Earth Sciences
http://www.vjs.ac.vn/index.php/jse

\title{
Sea-level rise and resilience in Vietnam and the Asia- Pacific: A synthesis
}

Luc Hens ${ }^{*}$, Nguyen An Thinh ${ }^{2}$, Tran Hong Hanh3, Ngo Sy Cuong4, Tran Dinh Lan5, Nguyen Van Thanh ${ }^{6}$, Dang Thanh Le ${ }^{7}$

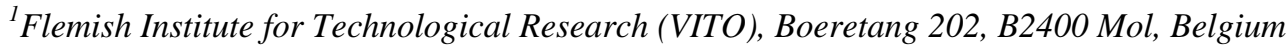

${ }^{2}$ Centre for Advanced Research on Global Change (HUNRE), Hanoi, Vietnam

${ }^{3}$ Hanoi University of Mining and Geology, Hanoi, Vietnam

${ }^{4}$ Vietnam Natural Resources and Environment Corporation, Hanoi, Vietnam

${ }^{5}$ Institute of Marine Environment and Resources (VAST), Da Nang Street, Hai Phong, Vietnam

${ }^{6}$ Ministry of Public Security, Hanoi, Vietnam

${ }^{7}$ Institute of Administrative Science, National Academy of Public Administration, Hanoi, Vietnam

Received 31 August 2017; Received in revised form 18 January 2018; Accepted 19 January 2018

\begin{abstract}
Climate change induced sea-level rise (SLR) is on its increase globally. Regionally the lowlands of China, Vietnam, Bangladesh, and islands of the Malaysian, Indonesian and Philippine archipelagos are among the world's most threatened regions. Sea-level rise has major impacts on the ecosystems and society. It threatens coastal populations, economic activities, and fragile ecosystems as mangroves, coastal salt-marches and wetlands. This paper provides a summary of the current state of knowledge of sea level-rise and its effects on both human and natural ecosystems. The focus is on coastal urban areas and low lying deltas in South-East Asia and Vietnam, as one of the most threatened areas in the world. About $3 \mathrm{~mm}$ per year reflects the growing consensus on the average SLR worldwide. The trend speeds up during recent decades. The figures are subject to local, temporal and methodological variation. In Vietnam the average values of $3.3 \mathrm{~mm}$ per year during the 1993-2014 period are above the worldwide average. Although a basic conceptual understanding exists that the increasing global frequency of the strongest tropical cyclones is related with the increasing temperature and SLR, this relationship is insufficiently understood. Moreover the precise, complex environmental, economic, social, and health impacts are currently unclear. SLR, storms and changing precipitation patterns increase flood risks, in particular in urban areas. Part of the current scientific debate is on how urban agglomeration can be made more resilient to flood risks. Where originally mainly technical interventions dominated this discussion, it becomes increasingly clear that proactive special planning, flood defense, flood risk mitigation, flood preparation, and flood recovery are important, but costly instruments. Next to the main focus on SLR and its effects on resilience, the paper reviews main SLR associated impacts: Floods and inundation, salinization, shoreline change, and effects on mangroves and wetlands. The hazards of SLR related floods increase fastest in urban areas. This is related with both the increasing surface major cities are expected to occupy during the decades to come and the increasing coastal population. In particular Asia and its megacities in the southern part of the continent are increasingly at risk. The discussion points to complexity, interdisciplinarity, and the related uncertainty, as core characteristics. An integrated combination of mitigation, adaptation and resilience measures is currently considered as the most indicated way to resist SLR today and in the near future.
\end{abstract}

Keywords: sea-level rise; coastal zone; hazard; resilience Vietnam; SE-Asia.

(C2018 Vietnam Academy of Science and Technology

\section{Introduction}

One of the most important hazards of

"Corresponding author, Email: Luchens51@gmail.com climate change is sea-level rise (SLR). It threatens ecosystems and the activities of up to half a billion people living in low coastal plains both directly and indirectly. Directly 
with its associated extreme weather events, floods, salinization of the ground table, and salt intrusion; indirectly by coastal erosion, habitat loss of mangroves, wetlands and other fragile coastal ecosystems. It threatens human coastal populations, and has social (health, livelihood, and migration) and economic (as income, blue economy) impacts primarily, but not only, in maritime cities. Obviously this elicits ethical issues and policy responses. Because sea-level rise is the world ecosystems' reply to increased temperatures in the past, these effects will continue during the decades and centuries to come, even if we manage limiting the average temperature increase to the Paris' policy goal of $2^{\circ} \mathrm{C}$.

Climate change impacts occur at a faster rate and more intense in South-East Asia than in many other parts of the globe. As a result, the coastal areas of the Asian-Pacific (AP) countries are among the most impacted and threatened ecosystems in the world. They provide major ecosystem services, they still host a rich biodiversity, and have many social and economic functions as tourism, industrialization, port development, agriculture, aquaculture, and trade. The coastal lowland of Vietnam e.g. produces over 80 percent of the GDP of the country and concentrates most of its economy. With an estimated 2 billion of inhabitants, the AP coastal area is intensively used by humans.

The growth of urban areas also impacts natural and semi-natural ecosystems, mainly through processes of land use changes (LUC and land reclamation). Tidal flats, wetlands, and mangroves disappear as their surface is eaten by urban development. A common sequence of events is that the city expands in the surrounding agricultural area which is also pushed back by industry, tourism, and trade development. Subsequently agriculture is established in more remote, green areas which lose their biodiversity.

This paper overviews the current knowledge and recently available data on sea level-rise and its main direct and indirect im- pacts in the Asia-Pacific region in general, and in Vietnam in particular. It focusses on SLR, its influencing factors and consequences, and the related resilience. It also deals with the consequences thereof: Floods and inundations, salinization, coastal shoreline changes, and impacts on mangroves and wetlands are summarized. Next to the description of the "state of the environment", major challenges for coastal areas and opportunities increasing their resilience are discussed.

\section{Materials and Methods}

\subsection{Study area}

This study covers three geographic levels:

- SLR and each of the associated elements are discussed in terms of worldwide trends and mechanisms.

- These general trends are projected on selected situations in the western Pacific and South Asia, the wider region of which Vietnam is part.

- Vietnam, for which not only country wide averaged figures, but also regional (North, Central, South) data and selected local findings and forecasts are provided.

\subsection{Literature search}

This review is based on the international scientific literature. The most recent publications were identified on Google Scholar, Science Direct, and Springer using the terms listed as keywords of this paper. Table 1 shows how vast the SLR literature is. SLR as such results in almost 5 million references in Google scholar. A gradual combination of terms allows reducing these figures to numbers that can be handled. The most relevant recent papers for each subject were selected.

This information was completed with recent (since 2011) texts and research books. This provides the paper with a more relevant master level and advanced studies character.

Whenever the text refers to the opinion of experts, this is indicated as such. 
Vietnam Journal of Earth Sciences, 40(2), 126-152

Table 1. International scientific literature databases on SLR (Last accessed on: June 12, 2017)

\begin{tabular}{|c|c|c|c|c|c|c|}
\hline \multirow{2}{*}{ Key words } & \multicolumn{3}{|c|}{ Number of references } & \multicolumn{3}{|c|}{ The most recent selected papers (since 2011) } \\
\hline & Google Scholar & Science Direct & Springer & Google Scholar & Science Direct & Springer \\
\hline SLR & $4,940,000$ & 215,733 & 210,951 & 18,600 & 59,395 & 4,287 \\
\hline Climate change & 208,000 & 5,291 & 10,488 & 16,500 & 2,992 & 3,517 \\
\hline Effects & 179,000 & 8,765 & 13,975 & 16,600 & 4,250 & 3,679 \\
\hline Vietnam & 13,700 & 447 & 937 & 1,890 & 213 & 227 \\
\hline Asia Pacific & 9,030 & 50 & 493 & 1.100 & 30 & 67 \\
\hline
\end{tabular}

\subsection{Measuring sea level rise and its associ- ated phenomena}

The reader will find that over-all a series of methods dovetailing both in the natural and the human sciences are used studying SLR. The methods listed below provide complementary information. Their combined use is important for the validation of the results. Selected examples entail:

Measuring sea water levels: In many places worldwide, especially near main harbors, sea levels/relative sea level changes (resulting from the combination of global thermal expansion and the more local and regional transfer of continental water to the ocean) are measured under standard conditions since the establishment of meteorological stations in the first half of the $19^{\text {th }}$ century. These networks measure meteorological (wind, atmospheric pressure, temperature, humidity) and oceanographic (wave sea level, salinity) data. The results in pioneering countries on meteo-data allow building timelines of 150-200 years. Most data are however available for the $20^{\text {th }}$ century. The Permanent Service for Mean Sea Level (PSMSL, www.pol.ac;uk/psmsl) publishes data from about 2000 sites worldwide (Cazenave and Le Cozannet, 2014). In Vietnam 17 stations along the coast of the mainland and the islands are used. 9 stations provide sufficiently long periods $(12960,1998$ 2014). The data are analyzed using ORKAN (European) and TIDE (Canadian) software.

Remote sensing (RS) and Geographic information systems (GIS): Research on SLR often needs handling extensive amounts of data at scales ranging from local to global. Dif- ferent aspects of the issue are measured using a wide array of RS/GIS strategies. This review suffices referring to a few examples:

Changes in sea surface height are monitored globally by satellite altimetry (Erban et al., 2014).

RS and GIS are useful and cost-effective technologies investigating environmental changes, and land use/land cover/landscape changes in particular (Serra et al., 2008; Tran Hong Hanh, 2017). These methods are able covering large areas with a high spatial resolution and a high temporal frequency (Were et al., 2013). This makes them indicated methods to study shoreline changes, vegetation alterations along coasts (as e.g. mangroves), and areal vulnerability.

Scenarios and models: A wide series of simple and complex models exist to predict SLR at variable time and geographic scales. Not only SLR, but also its effects on e.g. ecosystems as wetlands and marches are subject to modelling research. Models differ in the parameters they consider, which results in a wide range of characteristics of reliability, repetition, probability and uncertainty. Often models are based on scenarios taking into account different basic conditions of e.g. temperature increase, ocean circulation, $\mathrm{CO}_{2^{-}}$ uptake, mitigation, and atmospheric pressure, to list only these parameters. The most recent IPCC (2014) report uses in its projection of both global mean SLR and global mean surface temperature change forecasts 4 scenarios. These "representative concentration pathways" (RCPs), based on immission values of greenhouse gasses describe four different $21^{\text {st }}$ century pathways of greenhouse gas emis- 
sions atmospheric concentrations, air pollutant emissions and land use. The four scenarios include a stringent one (RCP2.6), two intermediate scenarios (RCP4.5 and RCP6.0), and a fourth one with very high greenhouse gas emissions (RCP8.5). Other approaches combine models and scenarios with on-going observations and paleontology data, increasing the degree of confidence of the results.

The RCP scenarios provide a basis for sea level scenarios. These take into account 8 principal components: Thermal expansion, glaciers and ice caps, Greenland ice sheet dynamics, Antarctic ice sheet dynamics, landwater storage, and glacial isostatic adjustment. The model not only provides figures for total sea level trends, but also the uncertainties characterizing these trends are assessed (Tran Thuc, 2016).

Indicators of past sea-level changes: Fossil corals provide data allowing to reconstruct sea levels in the archeological past, prior to the measurements which started around 1830 . Fossil corals are often well preserved in the fossil record and can be dated with uraniumseries methods. (Hibbert et al., 2016). Questionnaires: To understand knowledge, attitude, or practice of people in general and stakeholders in particular, questionnaire surveys, often combined with interviews, are applied. Questionnaires can be applied on a wide range of issues. On SLR they were used addressing both fundamental (as structuring transdisciplinary and transformative research - Delorme et al., 2016) and (directly) applicable issues. Examples of this latter entail:

- Expert opinions on a service for permanent sea-level information to protect urban ecosystems and other coastal areas (Holgate et al., 2012).

- The motivation of households which decided staying in flooded and threatened areas by SLR (Koerth et al., 2013).

- Farmers facing adaptation to SLR (Renaud, 2015).
- Fairness in adaptation to SLR (Graham et al., 2015).

Expert judgement/opinion and consensus building methods: In case of scientific debate on issues characterized by uncertainty, the pooled opinion of experts might indicate interesting trends. Most classical the method starts by inventorying the opinion of a group of experts (academics, politicians, decision makers, etc.) using a questionnaire. In a second step the answers of the experts are statistically weighted (e.g. taking into account the level of expertise and the confidence of the respondents). This approach has been used to assess SLR both quantitatively and qualitatively in long term projections, and on the evaluation of the impact of ice sheet melting on future SLR. The results are useful e.g. to streamline coastal risk management (Bamber et al., 2016; Merryn et al., 2016).

Delphi allows building consensus among the experts. The method is widely among social scientists and has been used e.g. in education, engineering, finance, military issues, bioengineering, and medical diagnosis. On SLR Delphi has contributed to theory formation (Le Cozannet et al., 2017), scenario establishment (Tett and Mee, 2015), vulnerability and consequences for habitats as mangroves (Chu et al., 2014), and applications as guidelines for environmental/strategic assessment (Lacerda et al., 2014).

As many other environmental problems SLR is complex and accounts for both physical-environmental and socio-economic aspects. Therefore it will be difficult describing it using single indicators, or analyzing it in unidimensional terms. Estimating and ranking the parameters involved in SLR can be approached by multi criteria analysis.

The Analytical Hierarchy Process (AHP) is one of the 4 approaches of multi-criteria analysis which are often used in environmental research. The method is of particular use in establishing composite indexes dealing with 
economic, societal, environmental, and/or sustainability contexts, as it allows weighting the individual components of the index.

AHP can be combined with the previously described methods. E.g. in combination with GIS, more complex and complete vulnerability maps can de produced (Nguyen and Woodroffe, 2016).

\section{Results}

\subsection{Sea-level rise (SLR)}

\subsubsection{Global trends}

Worldwide SLR is the result of two main mechanisms: the unexpectedly fast melting of the polar ice and the temperature increase mediated thermal expansion of the surface water of the oceans (the "steric" contribution). The polar ice melts faster than any model predicted 15 years ago (while during the last 50 years the arctic polar ice during winter time covered an area of over 14 million square kilometer of the Nordic Ice Sea, the 2016 data indicate this was 1.3 million square $\mathrm{km}$ less, the lowest value, since the parameter is measured). So do the glaciers and the mountain peaks. The highest temperature increases worldwide are recorded at the poles. As a result the ice melts. The IPCC scenario 8.5 predicts that only a limited amount of North Pole ice will remain by 2100 .

Water has its highest density at $4^{\circ} \mathrm{C}$. Both lower and higher temperature cause its expansion (the "custatic" contribution to SLR). The sum of both the steric and the custatic contribution is the "relative sea level rise" and reflects the rate of sea-level change at a specific location (Cazeneuve and Nerem, 2004). These two phenomena, of which the first one has a global character, while the transfer of continental water to the ocean is strongly influenced by local factors, explain the major regional and temporal variations in the sea level.

The most recent scientific consensus on worldwide climate changes (IPCC, 2014) pointed to an average increase of the com- bined land and ocean surface temperature of $0.89^{\circ} \mathrm{C}$ during the period $1901-2012$. This global average temperature speeds up during the past 65 years (since 1951) to $0.12^{\circ} \mathrm{C}$ per decade. Precipitation increased since 1901 averaged over the mid-latitude land areas of the northern hemisphere. The number of cold days and nights decreased worldwide, while the number of warm nights and days increased since 1950.

For the period 1900 until now observed SLR data exist for approximately 2000 sites, $10 \%$ of which provide data for a whole century. During the period 1901-2010, the global mean sea level rose by $0.19 \mathrm{~m}$ which corresponds with 1.6-1.8 mm per year. Also this effect increases over time, from $1.7 \mathrm{~mm}$ per year between 1901 and 2010 to $3.2 \mathrm{~mm}$ per year between 1993 and 2010.

For the period 1993 until now satellite altimetry data are available. They point to an almost linear increase over this period. They show a mean SLR increase of 3.2+/- $0.1 \mathrm{~mm}$ per year. This is the double of what the tide gauge data show. The interpretation of this doubling (e.g. speeding up of the SLR during recent decades) should be cautious as these satellite data cover only 25 years. Coral reef data showed that since 2-3 millennia, the mean sea level has remained quasi stable; the change did not exceed $0.5 \mathrm{~mm}$ per year during the last 2000 years. The combined evidence of all these studies shows that no acceleration occurred until the mid-to-late $19^{\text {th }}$ century (Cazenave and Le Cozannet, 2014).

Modelling work forecasts that the mean global surface temperature will continue to increase and that this effect will be pronounced more during the winter than in summertime. Also extreme temperatures show an increasing trend in particular for the coldest days $\left(5-7^{\circ} \mathrm{C}\right)$. The annual mean precipitation is expected to increase at high latitudes, and decrease in many mid-latitude and subtropical dry regions. As temperature extremes, precipitation extremes tend to increase by $5.3 \%$ for each $1{ }^{\circ} \mathrm{C}$ of surface temperature in- 
crease. The rate of sea-level rise will likely exceed $2.0 \mathrm{~mm}$ per year, resulting by 2100 in a global average increase of $36-52 \mathrm{~cm}$.

\subsubsection{The Asia-Pacific region}

The global average figures do not apply in every place worldwide. Regional climate variability, contributing to SLR, might be much larger than the global mean sea)-level in many parts of the globe. Average sea-level figures even obscure local variations (Hamlington et al., 2014). Strong regional variation might even indicate a reversal of the long term mean sea-level trends.

Causes of this regional variability are associated with dynamic variations in the ocean circulation and with an isostatic adjustment of the earth's crust to the past, and ongoing melting of the polar ice masses, and continental water storage and release. Coastlines are also affected by earthquakes and human influence (Stammer et al., 2013).

The Pacific region is particularly important in the regulation of the global and regional climate. The strengthened Pacific winds since the last years of the previous century contributed to rapid SLR in the western tropical Pacific, strengthened the Indo-Pacific ocean currents, increased the uptake of heat in the equatorial Pacific thermocline, and are associated with sea surface cooling in the eastern section of the area (McGregor et al., 2014).

Satellite altimetry data since 1993 show that also in the Asia-Pacific region, the sea level does not rise uniformly. In the western Pacific, rates of SLR were about three times faster than the global mean rate. In the eastern Pacific they were slower than the global mean. Although the whole region is affected by (mainly increasing) variations the highest increases are detected East of the Philippines, and North-East of Australia (Cazenave and Le Cozannet, 2014).

Islands in the Asia-Pacific region require particular attention for SLR. A study on its likely impact on 4447 islands in 10 insular biodiversity hotspots concluded that between
6\% (when the sea level increases by $1 \mathrm{~m}$, which is a reasonable expectation by 2100) and $19 \%$ (under the hypothesis of a $6 \mathrm{~m}$ increase) of the islands would be entirely submerged. Most significant loss was expected for islands of the Philippine archipelago (Bellard et al., 2014). The data are also in line with the islands Indonesia already lost as a result of SLR.

\subsubsection{Vietnam}

The observed trends in Vietnam follow the global trends: Increasing average annual and extreme temperatures, decreasing amounts of rain in the North, and increasing rain in the South, and more frequent droughts during the dry season.

- Average annual temperatures increased by $0.62^{\circ} \mathrm{C}$ during the period $1958-2014$, which coincides with $0.1^{\circ} \mathrm{C}$ per decade.

- Annual rainfall decreased in the North, while it increased in the South.

- Extreme temperatures increased in most climatic regions.

- Droughts in the dry season are more frequent.

- Extreme rainfall decreased in the Northern delta, but increased in the South-Central and in the Central highlands.

- The number of strong typhoons show an in creasing trend

Box 1 (MORE, 2016)

Early data showed recorded SLR varying between 1.75 to $2.56 \mathrm{~mm}$ per year. Most of the increase was attributed to thermal expansion and the melting of glaciers and ice caps. This is in agreement with the observed rise in sea levels worldwide. More recent scenarios show that by the beginning of this century the SLR in Vietnam is above the global average. Observations at tide gauges show an average increase of $3.3 \mathrm{~mm}$ per year during the period 1993-2014. The highest rate was found at Phu Quy $(5.5 \mathrm{~mm} / \mathrm{y})$ and a decrease by $5.7 \mathrm{~mm} / \mathrm{y}$ was noticed in Hon Ngu. The levels in the southern and eastern parts of the East Sea ("South China Sea") are considerably above 
these in the other regions, and in particular above these along the northern coast.

SLR observations by satellites cover larger areas than the tide gauges and result in higher figures. By 2050 the minimal ICP scenario (RCD 4.5 - after the Paris 2016 conference of the Parties of the Climate Change Convention, the most likely scenario) estimates an average increase of $22 \mathrm{~cm}(14-32 \mathrm{~cm})$, and by the end of the century of about $53 \mathrm{~cm}(32-76 \mathrm{~cm})$. More drastic scenarios (RCP 8.5) foresee average increases of $25 \mathrm{~cm}(17-35 \mathrm{~cm})$ in 2050 and $73 \mathrm{~cm}(49-103 \mathrm{~cm})$ by 2100 (MONRE, 2016). It is most uncertain how many of Vietnam's over 3000 islands will be submerged.

\subsection{Influencing factors}

\subsubsection{Extreme weather events: Global trends}

Tropical cyclones, also referred to as hurricanes, attain wind speeds between 18 and $33 \mathrm{~m} / \mathrm{s}$ and are formed in warm waters located in the tropics. They rotate in a counter clockwise circular motion in the northern hemisphere. From a conceptual point of view it is easy to understand that their frequency, intensity, timing and distribution is related to climate change and more in particular with the associated temperature and SLR changes. However during the period 1970-2004 the total number of hurricanes worldwide, and the number of cyclone days, on average did not change. On the other hand there is a significant oscillation in the number of tropical cyclone days and the number of tropical storms of the strongest, most impacting categories (4 and 5). The latter figure almost doubled during 35 years after the early 1970s (Webster et al., 2005). Over-all global figures provide limited evidence ("low confidence"/ IPCC, 2014) on the causal link between tropical cyclone activity and global changes. However it is "likely" that extreme sea levels have increased since the 1970s, mainly as a result of SLR.
This rather reticent position of the IPCC (2014) is mainly explained by the shortage of studies in this domain.

Monsoons and tropical storms are not the only climate change related extremes. In combination with heat waves, drought and wildfires, they reveal significant vulnerability and exposure of coastal natural and human ecosystems to current climate variability (IPCC, 2014).

\subsubsection{Asia-Pacific}

The West Pacific Ocean basin witnessed very strong and impacting tropical storms during recent years. This is the region, worldwide, where intense storms happen most frequently. As shown in Table 2, category 4 and 5 tropical storms significantly increased when comparing the periods 1975-1989 and 19902004, while the maximum intensity of the storms remained stable (Webster et al., 2005).

Table 2. Number of category 4 and 5 tropical storms by basin (Webster et al., 2005)

\begin{tabular}{|c|c|c|c|c|}
\hline \multirow{3}{*}{ Basin } & \multicolumn{4}{|c|}{ Period } \\
\hline & 197. & $5-1989$ & 199 & $0-2004$ \\
\hline & Number & Percentage & Number & Percentage \\
\hline $\begin{array}{l}\text { East Pacific } \\
\text { Ocean }\end{array}$ & 36 & 25 & 49 & 35 \\
\hline $\begin{array}{l}\text { West Pacific } \\
\text { Ocean }\end{array}$ & 85 & 25 & 116 & 41 \\
\hline $\begin{array}{l}\text { Southwestern } \\
\text { Pacific }\end{array}$ & 10 & 12 & 22 & 28 \\
\hline
\end{tabular}

This is based on and confirmed by local cases which do not show major changes. A study on the relation between SLR and changes in extreme storm events based on historical data and using four models, did not reveal significant changes in the weather extremes to be expected (Cannaby et al., 2015). The authors suggest that the behavior of wave and storm extremes in one year is independent of the behavior of the extremes during neighboring years.

The relative lack of understanding the origin, intensity and frequency of tropical cyclones also explains why they are difficult to 
predict. Models using satellite observations and statistical analysis techniques do not allow predicting their identification and pathways for timeframes of 3 to 5 days ahead (Barnes, 2014).

\subsubsection{Vietnam}

The extreme weather conditions are important in assessing sea-level extremes. Typhoon surge is a rise in sea-level which is directly caused by a typhoon. In Vietnam the highest surges that occurred were noticed along the Nghe An - Ha Tinh coast $(400 \mathrm{~cm}$ above the average high water level). Modeling shows that the highest typhoon surge that may occur amounts to $450 \mathrm{~cm}$. The lowest extremes $(150 \mathrm{~cm})$ are measured in the coastal areas around Da Nang, Phu Yen, and Binh Thuan (Tran Thuc et al., 2016).

These typhoon surges (may) cause significant economic damage to infrastructure as dykes and urban assets. They are a threat to human health and migration. They increase the budgets to improve resilience. Indicators as the number of rescue operations and spills, in particular in the southern Vietnamese marine water, point both to an extension of the monsoon season and increasing intensity of the storms.

\subsection{Effects of sea level rise}

\subsubsection{Floods and inundation}

Global trends: climate change significantly disturbs the water cycle by changing precipitation patterns and SLR, which increases the risk of flooding. On its turn this causes environmental damage in particular in low elevation coastal and delta zones around the world. New regions will become vulnerable to flooding and areas that already flood in the past may experience increases in both frequency and depth (Bilskie et al., 2014).

Coastal areas combine a huge and dense population with intense economic, education, and cultural activities. More than one third of the world population lives near the coast or at least $100 \mathrm{~km}$ from the coastline, and this percentage will increase (Goltermann et al., 2008). Most of the world's megacities are located in the low-elevation areas near the sea, and many of them are situated in large deltas.

Asia-Pacific: these worldwide trends definitely apply to the wider Asia-Pacific area and Vietnam as an intrinsic part of it. Neumann et al. (2015) assessed the number of people in the low-elevation coastal zone in 187 countries in combination with the number of people exposed to flooding storm surge events. The results showed that the risk is highest in Asia. Populations in China, India, Bangladesh, Indonesia, and Vietnam are most at risk.

In Indonesia urban expansion is particularly rapid on the island of Java. It has been estimated that from 2000 to 2030, increases in exposure will elevate flood risks by, on average, $76 \%$ and by $120 \%$ for river and coastal floods respectively (Muis et al., 2015). A prospective study on flood risks in Bangkok, Thailand (after the impacting 2011 floods) showed a progressively, although not linear, increase of coastal flooding and its impact on key-coastal infrastructure in the 2050s, 2080s, and by 2100 (Duyandyiwa et al., 2015).

Vietnam: Vietnam's mainland has a coastline of $3260 \mathrm{~km}$ and in the center of the country a narrow hinterland with varying landscapes. The Red River delta in the North and the Mekong-delta in the South are two main lowland delta areas. A SLR of $100 \mathrm{~cm}$ coincides with an inundation risk area of about $16.8 \%$ in the Red River delta, $1,47 \%$ in the central coastal provinces, $17,8 \%$ around Ho Chi Minh City, and $38.9 \%$ of the Mekongdelta. Islands of the Van Don group, Con Dao, and Phu Quoc have a high inundation risk (Tran Thuc, 2016). The regional differences are illustrated on the inundation risk map of Vietnam (Figure 1) where the main lowland deltas and the areas bordering the Gulf of Thailand show the highest risk figures. These 
Vietnam Journal of Earth Sciences, 40(2), 126-152

areas concentrate the economic activity, increasing areas of aquaculture, but also seramong which intensive rice agriculture and vices, tourism and trade.

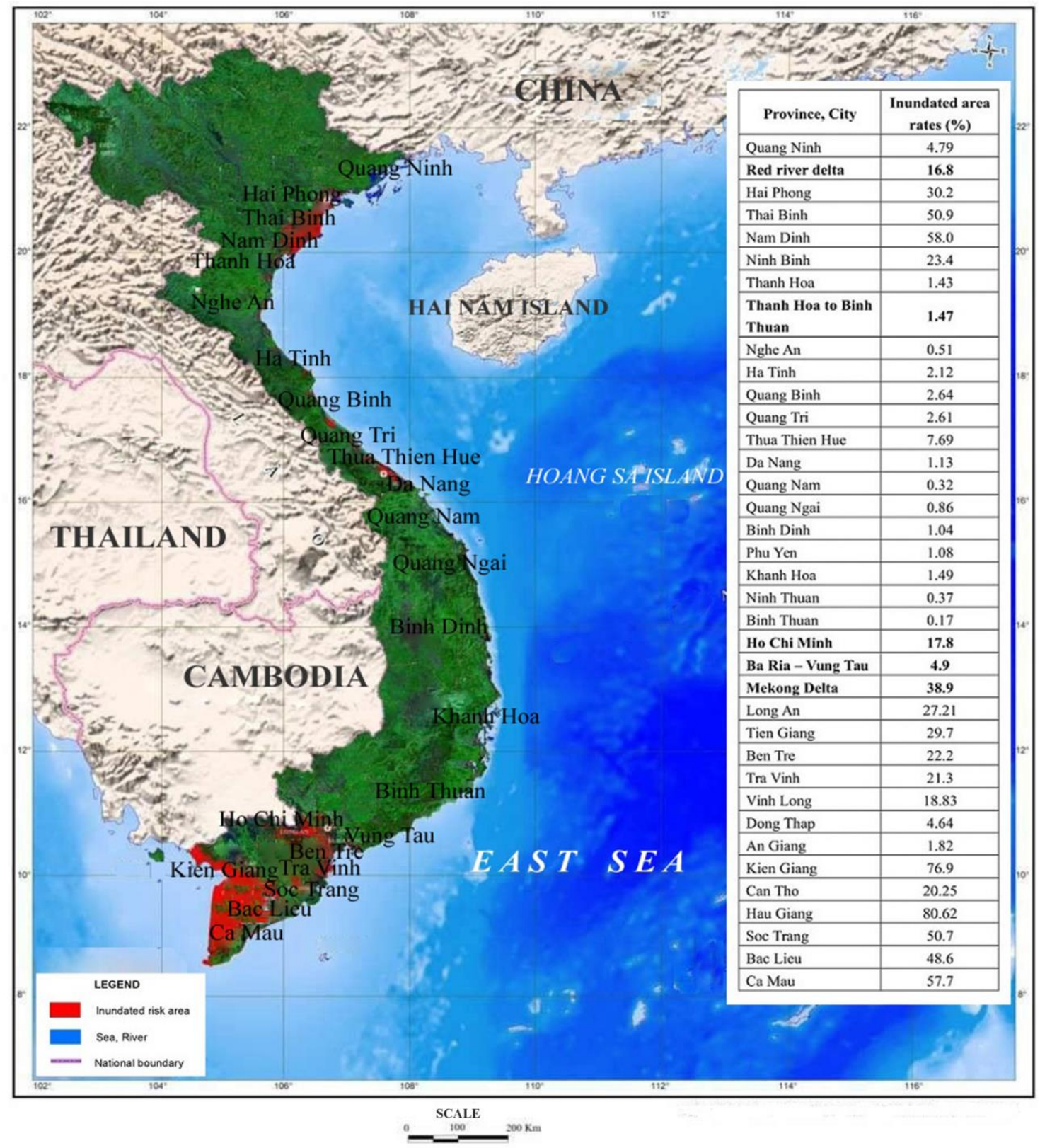

Figure 1. Inundation risk map of Vietnam for the $100 \mathrm{~cm}$ SLR scenario (MONRE, 2016)

On top of these anthropocentric effects, also ecological values as biodiversity and landscapes are affected. The MONRE 2100 scenario forecasts that along the North) Central coast SLR will inundate 61.129 ha or $1.23 \%$ of the existing natural area (Nguyen An Thinh and Hens, 2018).

Vietnamese people perceive these risks quite correctly. Research on the perception of people in the highly by storms, floods and in- 
undations affected Ky Anh District, shows that SLRE, floods and heavy rain are perceived as the most impacting climate change intensified phenomena on agri and aquaculture, livestock, households, property and income (Nguyen An Thinh et al., 2017).

\subsubsection{Groundwater extraction and salinization}

Global trends: Groundwater resources make up about one third of the earth's freshwater and are under stress in many places worldwide. Groundwater has an increasing role in public water supply. As a primary resource of clean water it serves more than 1.5 billion people. The increasing share of groundwater to the public water supply is related to its advantages over surface water: Its chemical and environmental quality, and its inexpensive treatment as it is better protected from contamination (Arustiene et al., 2013). This results in an increasing number of locations where the withdrawal of groundwater exceeds its recharge.

Quality, recharge and extraction are affected by SLR and inundation. Higher sea water levels increase the level of the water table, which in turn results in subsurface flooding. This impacts ecosystems and infrastructure. Moreover, fresh water pumping from coastal aquifers lowers the water table below sea level, which increases salt water intrusion, merely by vertical infiltration through soil channels (Anderson and Al-Thani, 2016). Inundations increase the surface which is vulnerable for this type of intrusion. Depending on the geomorphology and the geological structure of the soil, $20 \mathrm{~cm}$ of SLR leads to substantial changes in the depth of the water table and the extent and depth of saltwater intrusion (Masterson et al., 2014).

Salt intrusion occurs when in low-land estuaries, river discharge and groundwater replenishment when rainfall is insufficient. These conditions allow salt water from the sea to penetrating inland (Be, 2007). The high density of local canals and drainage systems allow saline water to intrude in many parts of deltas even far from the main river channels (Hashimoto, 2001). Saline water also intrudes into the soil and affects its properties (Lang et al., 2004).

Salinization occurs worldwide, especially the coastal regions. For example, in the Modaomen Estuary in China, the increasing salt intrusion threatens the freshwater supply, especially in the coastal cities Zhongshan, and Zhuhai in Guangdong Province and in Macau (Gong, 2011). In the Incomatiestuary (Mozambique), (Brockway et al., 2006) provides another example of salinization of groundwater. The Ganges, Brahmaputra, Meghna (GBM) catchment area covers 1.8 million square kilometers of India, Nepal, Bhutan, Bangladesh and China (Aerts, 2000), and has increasing salt intrusion.

Inhabited islands request particular attention in this context. Sufficient rainfall recharge on oceanic islands results as a rule in a freshwater lens, whereby a volume of freshwater exists above the sea water, as a result of density differences between both types of water. Freshwater lenses have been described as some of the most vulnerable aquifer systems in the world for sea water intrusion (Morgan and Werner, 2014).

Asia-Pacific: Groundwater is an important asset for households, industry, and in all countries of the Asian-Pacific area. The Mekongdelta, shared between Cambodia and Vietnam, is populated by more than 20 million people. The groundwater exploitation in this area increased dramatically in recent decades. From a limited number in the 1960 s, today more than one million wells access groundwater, which results in a steadily decline of many aquifers over extensive regions. Most of the delta lies within $2 \mathrm{~m}$ of the current sea level and is highly vulnerable to the additive effects of pumping and SLR (Erban et al., 2014). Similar situations exist in Malaysia, Indonesia, the Philippines and Thailand. 


\section{Vietnam Journal of Earth Sciences, 40(2), 126-152}

Coastal cities and their aquifers show equally high risks (Rasmussen et al., 2017). Bangkok is on the long and increasing list of examples of cities worldwide of which significant portions subsided in response to high groundwater extraction rates (Erban et al., 2014).

Vietnam: There is currently no formal evaluation of the groundwater extraction, but the issue is recognized, and a country wide project is ongoing. Results are expected by 2020 (Tran Thuc et al., 2016). Salinization is currently an important issue all over the Mekong-delta, and in the $\mathrm{Ca} \mathrm{Mau}$ province in particular (Nguyen and Savenije, 2006). Salinization reaches its maximum during the dry season when the flow of fresh water from rainfall and the Mekong River is more limited. In $\mathrm{Ca} \mathrm{Mau}$, the peak of the dry season, the affected area and the severity of the phenomenon vary with the rainfall during the seasons. SLR directly affects coastal areas, and likely increases salinization. Based on the expected $50 \mathrm{~cm}$ increase in sea level by 2070 in Southern Vietnam, one expects salinization affecting crop yields, or even crop failure, and loss of fruit trees, inducing high costs to shift to new crops, livelihood patterns, or migration (IMHEN, 2011).

Saline intrusion in $\mathrm{Ca}$ Mau attributes to the complex interaction of tidal regimes (amplitude and period) in the East Sea (South China Sea) and the Gulf of Thailand, and the increasing influence of sea level rise. In addition, El Nino variations influence the rainfall regime, prolonging the dry season, postponing the start of the rainy season, and reducing the amount of rain, which causes the lowest groundwater levels in 90 years (Water Resources Directorate, 2016). This low groundwater table attracts saline water inland wards. Hence, salt intrusion in rivers starts almost two months earlier than in the past. Extraction of groundwater from the aquifers is still unplanned, poorly monitored and hardly assessed. Insufficiently managing aquaculture results in water pollution and enhances salt intrusion (Water Resources Directorate, 2016). The monitoring network for groundwater in $\mathrm{Ca}$ Mau is sparse (83 monitoring points in the whole Southern area, as a result each sampling point covers an area of $760 \mathrm{~km}^{2}$ ) and outdated.

The salinity map of Ca Mau for April 2016 shows serious salinization which was built up over the last 100 years (SIWRR, 2016) (Figure $2 \mathrm{a}$ ). The map is based on the hydraulic models using Mike software and the salinity data of the 83 monitoring stations. The results show that the northern part of the Tran Van Thoi district, North of the Ong Doc River, and a part of the $U$ Minh district, still shows low salinity levels (from 0 to $1 \%$ ). However, the remaining part of the $\mathrm{Ca}$ Mau province is already affected by high to very high water salinity, ranging between 6 to more than $24 \%$. The isolated low salinity zone is most likely the result of efficient measures preventing salt intrusion along the coastline and the river canals. The projected 2050 salinity map of the Ca Mau province (IMHEN and Ca Mau PPC, 2011) (Figure 2b) shows that the entire $\mathrm{Ca}$ Mau province is at risk of salinization.

The groundwater in the Red River delta is merely brackish. The area experiences yearly salt intrusions in the rivers of the delta at long distances from the confluence. The Tra Ly River for instance experiences maximal salt water intrusion under average low-flow hydrolic conditions from 1989-2012 over a distance of $33.7 \mathrm{~km}$ land inwards from the sea. The situation is worsened by SLR and impacts rice irrigation and household water supply in the coastal area (Nguyen Van Hoang et al., 2017). 

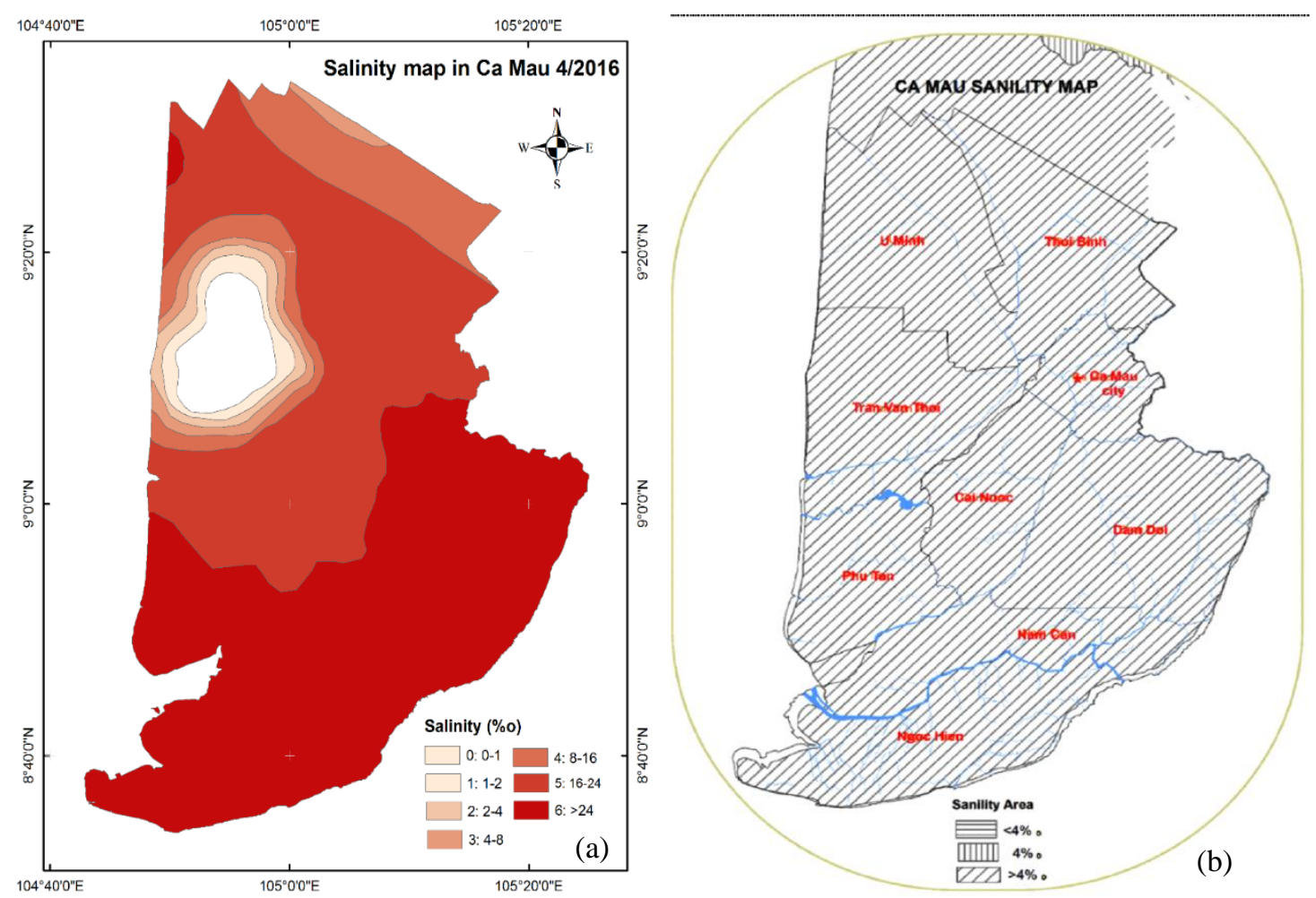

Figure 2. a- Salinity map in April 2016 of the Ca Mau province by the Southern Institute of Water Resources Research (SIWRR, 2016); b- Projected salinity map of Ca Mau province in 2050 by the Vietnam Institute of Meteorology, Hydrology and Climate Change (IMHEN and Ca Mau PPC, 2011)

\subsubsection{Coastal shoreline changes}

Global: SLR, increasing storms and flood risks make it likely that shallow coastal areas will be submerged. Intensification of coastal erosion and landslides caused by the increased water levels at river mouths are equally possible. However, research on the impact of SLR on shoreline changes over the last decades shows a range of responses:

- Several studies show examples of the expected shoreline retreats as a net result of erosion and deposition processes.

- Other studies point to annual net gains of coastal land.

- Still other publications checked whether decadal to multi-decadal coastal erosion is more likely when SLR speeds up.

- Also area specific aspects and other processes as effects of waves and storms, accre- tion rates and land reclamation influence dynamic coastline erosion (Cazenave and Le Cozannet, 2014).

This makes coastal shoreline changes a complex phenomenon which is not only affected by SLR, but also by sedimentation of (irrigation dams influenced) tidal inlets and the dredging of shipping channels, mentioning just these factors as examples.

In spite of the wide range of interpretations of the varying research outcomes, and the uncertainty which is intrinsically linked with it, global analyses of the erosion of sandy beaches under different SLR scenarios (0.2-0.8 m) show an estimated global loss of 6000$17000 \mathrm{~km}^{2}$ of open sandy coast land which may be lost during this $21^{\text {st }}$ century (Hinkel et al., 2013). Narrow, less than 20 meter wide beaches with a limited terrestrial sediment supply, a substantial coastal development and 
limited (existing) coastal protection, are particularly vulnerable (Monioudi et al., 2017).

Changes of coastlines and beaches have significant socio-economic impacts on the dense populations living in coastal areas. Beaches in particular, have an important role in coastal protection, recreation, and tourism. Changes in the coastline shape will worldwide force an estimated 1.6-5.3 million people to migrate (Hinkel et al., 2013).

Small islands and deltas are most impacted by SLR mediated erosion and flooding. At the limit islands disappear. The threats of SLR, erosion and ecosystem degradation on the low-lying Oceania islands of the Carteret atoll, Tuvalu and Kiribati became iconic, partially because of the media attention (Farbotko, 2010; Connell, 2016), and the coastal protection targeted international aid programs (Donner and Webber, 2014). In Pakistan, one fifth of the Indus delta plain eroded since the river was first dammed in 1932. In China the northern shore of the Yellow River delta retreated 300 meter per year for the past 35 years (Gosan, 2014). Coastal erosion is not a phenomenon which stands alone. Erosion increases under the influence of typhoons and extreme weather events (Do Minh Duc et al., 2017).

Asia-Pacific: As many coastal regions in the world the sandy beaches, but also the tidal flats, the coastal cliffs, and the rocky shore platforms of SE Asia experience complex interactions of erosion and deposition of material. Typical for the coastal regions in this part of the world is the huge and dense population and its economies and livelihoods. This results in intense interactions between the natural and the human environment, influencing the shoreline development. Examples entail:

- The common land reclamation: Comparisons of topographic maps of Singapore reveal declines in total cover of intertidal coral reef flats from $170 \mathrm{~km}^{2}$ in 1993 to $9.5 \mathrm{~km}^{2}$ in 2011. During the same period sand and mud flats declined from $8.0 \mathrm{~km}^{2}$ to $5.0 \mathrm{~km}^{2}$.
- Irrigation dams do not only regulate amounts and timing of downstream water flows, but also make particles depositing behind the dam. Consequently less suspended material deposits at the coastal beaches, contributing to their regression.

- Coastal areas are also transformed by urbanization and aquaculture. The region hosts four of the top 10 world producers of shrimps and other aquaculture products (Vietnam, Indonesia, Thailand and the Philippines).

Urbanization, land reclamation, irrigation dams, and coastal aquaculture interact with coastal erosion and can have significant deleterious effects on coastal natural and human ecosystems (Williams et al., 2016).

Vietnam: Vietnam experiences the erosion trends which affect the Asia Pacific subcontinent at large. Coastal erosion has however a multi-causal origins. Coastal erosion at the beach of Cua Dai near the world heritage site of Hoi An in the central region of the country, provides an example. Coastal erosion is most serious, in such that some $20 \%$ of the beach is forecasted to disappear by 2020 . Major causes of the erosion include the changes in sediment deposition as a result of the new hydropower dams on the Vu Gia and Thu Bon rivers, illegal sand winning near the coast in the East Sea (South China Sea), and sea level rise (Nguyen An Thinh et al., 2017). In this multi-causal context also the following examples need to be situated:

- The Hai Hau district has the most seriously eroded coast of the country. Although erosion in this area occurred since the beginning of the $20^{\text {th }}$ century and a dike system protects the shoreline since the 1980 s, the erosion intensity during the period 1985-1995 was more than 1.5 times higher than during 19651985. In the Hai Chinh - Hai Hoa segment of the region the erosion speed was 10 to 20 meter per year on average. Non-representative extremes peaked at $400 \mathrm{~m} / \mathrm{y}$. During recent years (2004-2013) the SLR induced erosion 
rate accelerated with 0.2-0.3 m/y (Do Minh Duc et al., 2015).

- The beaches of Ky Anh, in the northern part of central Vietnam, retreat by meters a year during the last decades. The combination of SLR, storms, coastal erosion and floods results in the destruction of houses and infrastructure, among others in Ky Anh (Nguyen An Thinh et al., 2016; Do Minh Duc et al., 2017).

- Beaches in the southern-central province of Binh Thuan regress as a combination of coastal erosion and reduced sand deposition from the rivers, as a result of the upstream dams. The loss of beaches affects the attraction for recreation and the high investments the local authorities realized in tourism infrastructure.

\subsubsection{Mangroves}

Global: Mangroves are woody trees and shrubs. They are found along the upper intertidal shorelines and the deltas in the tropics and sub-tropics. Mangrove ecosystems are among the most productive and valuable ecosystems in the world (Kuenzer et al., 2011). Mangrove forests provide timber, host fish resources, protect the coast, are a source of energy from the waves, mitigate the impact of hurricanes, cyclones, tsunamis and storm surges, regular carbon sequestration, and as an important biodiversity source (McIvor et al., 2012). The persistence of mangroves increases resilience because it implies the ability to cope with moderately high rates of relative SLR (Woodroffe et al., 2016). Mangrove forests are typical in tropical and sub-tropical regions; they stand high salinity, high temperatures, and high sedimentation rates and they grow on muddy flats (Alongi, 2002).

A wide range of studies called for increasing the awareness of decision makers, local people, and the public at large, recognizing the value and the services of mangrove ecosystems. The total mangrove area in the world was estimated at $137760 \mathrm{~km}^{2}$ in the year 2000 . This was the result of a reduction by $35 \%$ of mangrove cover between 1980 and 2000 (Millennium Ecosystem Assessment, 2005). During the period 2000 to 2005 , more than 100,000 hectares of mangroves disappeared worldwide every year (FAO 2007). Current mangrove deforestation is estimated occurring at a rate of $1-2 \%$ per year. At this rate of loss, all existing mangrove forests will lost during the next 100 years due to deforestation and SLR (Duke et al., 2007).

While most of the mangroves are found near the sea, delta areas are of particular concern as many of them disappear faster than the coastal forests, while they are important in coping with SLR (Woodroffe et al., 2016).

The SLR-mangrove relation is complex. On the one hand side mangroves protect the hinterland against the effects of SLR; on the other hand SLR is one of the causes of the reduction of mangrove forests and many tropical deltas experience deep subsidence, which increases relative SLR. Moreover this mechanism counteracts coastal erosion and the impacts of extreme weather conditions.

The long term, geological record indicates that mangroves were locally eradicated but moved into new habitats (Alongi, 2015). Pushed back by SLR, mangroves can move landward, but this migration opportunity is in many places obstructed by coastal development.

These elements make it difficult forecasting the future of mangrove forests. Main elements of this prediction entail:

- Decline along arid coasts as salinities increase.

- Decline with reduced sediment deposition and SLR, which is particularly important in the Asia-Pacific region).

- Decline where limited upland space to colonize is available.

- Expansion over latitudinal ranges.

Over-all mangroves will continue to survive in the future mainly because they will 


\section{Vietnam Journal of Earth Sciences, 40(2), 126-152}

expand in new habitats. In the future next to SLR, deforestation is a main threat (Alongi, 2015).

Asia-Pacific: The Indo-Pacific region has the largest mangrove cover in the world. All over the region the mangrove forests decline due to reduced sediment deposition caused by damming rivers and by other human activities. Sediment availability can enable mangroves to maintain. An intensive Indo-Pacific study of SLR/soil surface elevation gain showed that for $69 \%$ of the sites the current rate of SLR exceeds elevation gains (Lovelock et al., 2015).

Mangroves in deltas need particular attention. A study of change patterns spanning 30 years, on five main Asia-Pacific delta areas showed next to a net contraction of $7.6 \mathrm{~km}^{2}$, varying results for the five study areas. Net reductions were found in the GangesBrahmaputra, Fly, and Kikori-Punari deltas. The mangrove area in the Mekong-delta was relatively stable with a modest $0.14 \%$ decline over 20 years. The largest increase $(2.7 \%)$ occurred in the Irrawaddy delta (Sheaman et al., 2013).

Vietnam: The Vietnamese part of the Mekong-delta, with its dense population and a rapid economic development, experienced a decline of swamp forest during the Vietnam War, and the period of socio-economic development after the War in 1975 (Giri et al., 2003). Land use in the 12 provinces of the Mekong delta in Vietnam allows double-crop rice systems in the northern part, triple-crop rice agriculture in the central part, and shrimp farming alternating with single-rainy season rice crops, and mangrove and Melaleuca forests in its southern part. This suggests that floods and salt significantly influence this pattern (Sakamoto et al., 2006).

Previous studies documented the main LUCC processes in several districts (Ngoc Hien, Nam Can, Cai Nuoc, Tran Van Thoi) of Vietnam's most southern province, $\mathrm{Ca} \mathrm{Mau}$ during different periods. Comparison of the results of these studies shows major declines of the mangrove and Melaleuca forests (Binh et al., 2005; Thu, 2006; Lam Dao Nguyen et al., 2011; Tran et al., 2015), the increase of aquaculture ponds, and the regression of aquaculture along the coast.

In the Cai Nuoc District, the mangrove forest area declined by $75 \%$ between 1963 and 2003. Here forest was converted into aquaculture and agricultural land (Binh et al., 2005). The mangroves of the Ngoc Hien District covered over $72 \%$ of the total area in 1965 , but only nearly half this surface in 2001 (Thu, 2006). While mangroves both in the Ngoc Hien and Nam Can Districts of Ca Mau covered over 150,000 hectares before 1961, $40 \%$ was lost during the period between 1983 and 2007 (Lam Dao et al., 2011). Mangrove forest conversion (reduction of $90 \%$ ) occurred mainly in the southwest in the Tran Van Thoi District during the last 40 years from 1973 to 2011 (Tran et al., 2015).

The major factors contributing to the loss of forest cover include the Vietnam War, the expansion of paddy rice cultivation, and shrimp farming, the new economic and land policies, , and the economic development (e.g. wood extraction, high population pressure in coastal areas, and coastal industrialization). The effect of salinization on mangrove forest decline is likely but still uncertain and insufficiently understood (Binh et al., 2005; Thu, 2006; Tho et al., 2008; Lam Dao Nguyen et al., 2011; Van Lavieren et al., 2012; Tran et al., 2015). Therefore SLR currently plays also a vital role in the mangrove decline in Vietnam. Mangroves in Vietnam's southern regions will continue to decline mainly as a result of sediment yield declines, and SLR. This makes Ca Mau and the southern part of the Mekong-delta one of the most threatened hot spots worldwide (Alongi, 2015).

\subsubsection{Wetlands}

Global: Together with mangroves, swamps and lagoons support a rich coastal biodiversity 
and provide important ecosystem services. The impact of SLR on both mangroves and wetlands is an important indicator for the threats to biodiversity.

Wetlands cover an estimated $6 \%$ of the earth's land. Next to harboring an impressive biodiversity, they provide multiple biophysical (ecological, hydrological, biochemical), socio-economic services, and scenic beauty. Marine vegetated habitats (seagrasses, salt marshes, macro-algae and mangroves) e.g. occupy $0.2 \%$ of the ocean surface, but contribute $50 \%$ of carbon burial in marine sediments. They are threatened by the intensive and fast developing use (urbanization, agriculture, aquaculture, industrialization, tourism) people make of the coastal areas. Depending on the region $30-90 \%$ of the wetlands worldwide have been destroyed or are highly impacted. Climate change scenarios, including SLR forecasts, predict additional stress on wetlands as a result of flooding and temperature changes (Junk et al., 2013). By 2080, SLR could cause the loss of up to $22 \%$ of the world's coastal wetlands. Combined with other losses due to direct human action, as winning land, up to $70 \%$ of the world's coastal wetlands could be lost by the 2080s (Nicholls, 1999). In view of their importance in the carbon balance, the loss of a third of the global cover of these ecosystems involves a loss of $\mathrm{CO}_{2}$-sinks and the emission of the same greenhouse gas Duarte et al., 2013).

Coastal wetlands are particularly vulnerable to increasing sea levels. As the sea rises, the edges of the marshes, tidal flats, and swamps erode, and new wetlands will emerge in currently dry areas. The newly formed wetlands could well be much more limited in surface than the areas lost. Wetlands in zones with small tide ranges are most vulnerable. With a $50 \mathrm{~cm}$ SLR, losses of $46-59 \%$ of global coastal wetlands are expected. With a $110 \mathrm{~cm}$ SLR the figure increases to $78 \%$ (Spencer et al., 2016). Also the environmental quality of the coastal marshes is closely related with the status of the wetlands.

Asia-Pacific: The islands in the Pacific (next to these in the Caribbean and the Indian Ocean) are expected experiencing the largest relative increase in SLR and flood risk.

In the Yellow Sea region of East Asia tidal wetlands protect over 60 million people from storms and inundations. In this area urban, industrial and agricultural developments make tidal flats disappearing at a rate of $1.2 \%$ annually during the past 30 years. Historical references show that up to $65 \%$ of the tidal flats were lost during the past 50 years, which makes the protection and the restoration of the remaining coastal ecosystems imperative (Murray et al., 2014).

Also projections of likely situations in the future point to South-East Asia as a most vulnerable region. A study on the impact of SLR on the wetlands in 86 developing countries pointed to East Asia and the Pacific as two of the four most threatened areas worldwide. The islands in the Pacific are expected experiencing the largest relative increase in flood risk. Among the 6 countries which will bear most wetland losses, Vietnam and China are mentioned (Blankespoor et al., 2014).

Vietnam: Central Vietnam hosts North of Da Nang some of the most beautiful and diverse wetlands of the world. The over-all situation of the wetlands in the country is comparable with this around the Yellow Sea. The affected and threatened area of Vietnamese wetlands is estimated covering $1.700 \mathrm{~km}^{2}$, which coincides with $60 \%$ of the country's wetlands. A one meter SLR, which is qualified as possible under the prevailing PCR scenarios, is expected resulting in the loss of $40.000 \mathrm{~km}^{2}$ of land, among which $5.000 \mathrm{~km}^{2}$ of rice paddy in the northern Red River delta and $20.000 \mathrm{~km}^{2}$ in the southern Mekong River estuary and delta. This would seriously affect the populations living in these areas, not only societally and economically, but also in their 


\section{Vietnam Journal of Earth Sciences, 40(2), 126-152}

migration and relocation patterns (Tran Hong Hanh, 2017). Moreover, the problem is not only about surface loss. The main Vietnamese delta wetlands provide a diversity of recognized services to rice agriculture (Berg et al., 2017).

Over-all, although coastal and delta wetlands are seriously threatened by SLR, wetlands will survive. While many of the existing ones will disappear, they will move in the lower lying areas beyond their current borders. Landward barriers of lagoons will retreat through continuous migration. Also the hypsometry will adapt during the retreat process. The extent to which they will survive is difficult to predict as this largely depends on how human impacts interact with rapid SLR, and socio-economic factors that influence the transgression into adjacent land (Kirwan and Megonigal, 2013).

\subsubsection{Urban environments}

Global: SLR threatens primarily lowelevation coastal zones (LECZ - less than $10 \mathrm{~m}$ above sea level) and cities in particular. The threat of permanent inundation affects large groups of people both globally and locally. Worldwide LECZ account for an estimated $2.3 \%$ of the total land area of all coastal countries, but $10.9 \%$ of the population in 2000 . The average population density by that time was 241 people per $\mathrm{km}^{2}$, which is 5 times the global mean of 47 people per $\mathrm{km}^{2}$ (Neumann et al., 2015a). Locally, in Miama-Dade County, Florida, for example, a uniform elevation of $90 \mathrm{~cm}$ SLR would permanently inundate the residences of $5 \%$ of the population (Kopp et al., 2014).

Next to the current situation, forecasts foresee that SLR mediated coastal flooding will increase mainly because the low elevation urban land near the coast will increase. In 2000 , about $30 \%$ of the global urban land was located in high-frequency flood zones; by 2030 this figure is expected to increase to
$40 \%$. The surface of this urban land, worldwide, exposed to flood hazards is expected to increase 2.7 times by 2030 (Güneralp et al, 2015).

Not only the area at risk of SLP increases, also the number and the share of people living in these LECZ expands. Projections based on different models, taking into account a wide range of variables and uncertainties foresee a growth of the population in these areas from 625 million in 2000 to $879-949$ million by 2030. By 2060 the LECZ are expected to host 1.4-11.3 billion people (coinciding with 534 people per $\mathrm{km}^{2}$ under the lowest assumption (Neumann et al., 2015a). This increase of urban dwellers is the combined result of autonomous growth (fertility) and the net national and international in-migration driven by the socio-economic-cultural attraction of cities. These trends not only put more people at risk, but also alter biodiversity and critical ecosystem services which further put the sustainability of megacities under stress.

Several policy options exist to safeguard people and the urban assets from SLR associated floods. Spatial planning, preventing people to live in the LECZ at risk is the most indicated way protecting cities from floods. Moreover, next to technical-engineering interventions as dikes and wave-breaks, increasing attention is given to adaptation of green infrastructure and "eco-efficient" vulnerability reducing and urban resistance increasing mitigation measures. In establishing and developing these policies integration and coordination, promoting participation and the adaptive capacity of vulnerable groups, were identified as main challenges facilitating over-all urban resilience (Anguelovski et al., 2014).

Floods present society significant bills and increasingly impact budgets at all levels. Average global flood losses in 2005 were estimated at US\$ 6 billion, increasing to an estimated US\$ 52 billion by 2050 (Hallegate et al., 2013). 
Also the global costs of protecting the coast with dikes demand annual investment and maintenance costs estimated at US\$ 12-71 billion in 2100 (taking into account one has to prepare for larger disasters than we experience today. These high amounts of money are however much smaller than the cost of avoided damage, even without accounting for indirect costs of damage to regional production supply (Hinkel et al., 2014).

Asia-Pacific: Research on urban SLR responses is characterized by a geographical bias towards cities in economically more developed countries. More recently also cases in Asia have been published (CastanBroto and Bulkeley, 2013; Muis et al., 2025). Over-all in developing countries in Asia the surface of LECZ is expected to increase faster than in industrialized countries (Güneralp et al., 2015)

On the Indonesian islands, urban expansion is particularly rapid in Java, which accounts for $79 \%$ of the national increase. From 2000 to 2030 increases in exposure will elevate the flood risk on average by $76 \%$ and $120 \%$ for river and coastal floods (Muis et al., 2015).

Also when it comes to the population living in the LECZ, Asia had most people in 2000 (461 million or $73 \%$ of the global LECZ population), and this is expected being the case also in 2030 and 2060. The Indonesian archipelago, Vietnam, China, India and Bangladesh are the 5 countries worldwide with the largest population share living in LECZ (Neumann et al., 2015).

Within the cities the peri-urban areas need specific attention. Peri-urban areas in East Asia are expected to expand by $40 \%$ of the total projected population growth. On policy, a study reviewing the responses to SLR in 100 big (over 1.3 million inhabitants) revealed that developing countries performed as well as industrialized countries on adaptation, carbon sequestration, transport, urban form and infra- structure actions. Only actions concerning the built environment (energy efficiency, low carbon energy, water efficiency) were lagging behind in developing countries (CastanBroto and Bulkeley, 2013). This illustrates that urban SLR policies go beyond restricting e.g. the development of low-lying land, but merely focus on constructive actions. To guide the responses to SLR that are socially and environmentally sustainable, urban planning needs to:

- Facilitate local ownership of adaptation responses.

- Promote action within and between the urban communities and with the authorities.

- Be fair in its application across space and time (Hurliman et al., 2014).

In conclusion, there is increasing evidence that in South-East Asia these major SLR related changes have implications for the existing environmental, social and economic systems.

Vietnam: Vietnam provides a series of pronounced illustrations of the global trends and the situation in Asia Pacific. Urban development increases flood risks along the coast and in the main deltas, due to local changes in hydrological and hydro-meteorological conditions.

Can Tho, as the biggest city of the Mekong River Delta, which faced impacting floods during recent years, illustrates the complexity of the problems in low elevation delta cities. The city faces:

- The effects of a $3 \mathrm{~mm}$ SLR during recent years, resulting in an expected $9-88 \mathrm{~cm}$ rise by 2100.

- An expected increase of climate change mediated river runoff.

- Increased urban runoff driven by imperviousness.

- More extreme rainfall as a result of the urban heat island effect of the expanding city.

The results of models combining these factors show that the flooding risk in Can Tho 


\section{Vietnam Journal of Earth Sciences, 40(2), 126-152}

increases significantly. In particular vulnerable areas and poorer communities will be affected.

The increase in the peri-urban area of Ho Chi Minh City, Vietnam's most important economic driver, and the biggest metropolitan in the South of the country, grew between 1990 and 2012 by converting $660.2 \mathrm{~km}^{2}$ of cropland. During this period 3.5 million people moved into the region, bringing the total population to nearly 12 million by 2012 . These data illustrate the peri-urbanization in the region (Kontgis et al., 2014).

In spite of these stressing situations Vietnam's policy is not always in line with the SLR associated threats. The urban growth ambitions of the city of Quy Nhon provide an example. In spite of a recent history of multiple catastrophic floods, the provincial Department of Construction proposed expanding the city's boundaries in low-lying agricultural areas nearby. This increases the flood hazards and applies for the next catastrophe. For the country it will prove a major challenge matching the growth pathway with the SLR related vulnerability (DiGregorio, 2015).

\section{Discussions}

This paper focuses on the impacting nature of climate change mediated SLR. The average global figure of the current $3 \mathrm{~mm}$ rise and its increasing trend are subject to both temporal and spatial variations. South-East Asia as a whole, and Vietnam in particular emerge as particularly threatened. This does not only apply to the direct (flood risks, salt water intrusion), but also the indirect consequences on natural and human ecosystems. The review shows the threats from SLR associated floods and influencing factors as extreme weather conditions to main ecosystem services as drinking water, and those provided by mangroves and wetlands. The text is not complete in this respect. Impacts on agriculture and industrialization are only mentioned, but not covered in depth. The issue is further complicated because SLR is one of the effects of climate changes. This makes SLR interlinked with the wide scope of climate change related issues. Therefore SLR should be considered in a wider context.

The review points to a series of transversal, cross-cutting elements on SLR:

- The complexity and the multiple interlinkages between SLR, its influencing factors and its effects. Groundwater-SLR links offer an example: Excessive use of groundwater not only affects the volume of the reserves, but also the quality and its degradation (arsenic, chlorine).

- Salinization is not only caused by the amounts which are withdrawn, but also by coastline transgression, various hydrogeological settings influencing the recharge patterns, salt intrusion, and residence time. The problem interferes with environmental quality, socio-economy, health and public water distribution.

- The flood issue provides another example: Timing, frequency and intensity of tropical storms and hurricanes alter coastal wetland hydrology, geomorphology, biotic structure, energetics and nutrient cycling. These selected examples show that one can address these issues only in a comprehensive way which requires focus and an interdisciplinary approach.

This characteristic of needed interdisciplinarity applies to all (direct and indirect) effects of SLR. SLR issues combine information from fundamental sciences, environmental management, technology, medicine, economics, justice and sustainability, just listing these selected elements. This makes the area prone to developing quantifiable frameworks integrating this wide range of aspects.

Closely linked with inter-disciplinarity and complexity is scientific uncertainty. Although climate changes and most of their direct and 
indirect effects in general, and SLR in particular, are happening beyond reasonable scientific doubt, a series of uncertainties requiring more research, exist. As demonstrated in the results section of this paper examples entail:

- The mechanisms governing the SLRextreme weather effects relationship.

- Only few dose-effect relationships have been described. Data on and knowledge about how many migrants coincide with a unit level of SLR, the economic impacts on wetlands, etc. will significantly contribute to SLR risk assessments.

Next to the above scientific considerations, a main question relates to "How do we handle the fundamental and associated effects of SLR?". The answer is since a few years invariable: mitigation, adaptation, increasing resilience and a targeted policy addressing the problems in a holistic, interrelated way.

Mitigation: The best way replying to the above threats is mitigating, if not eradicating, the emissions of greenhouse gasses. Decarbonization and carbon neutrality, moving society away from emitting excessive amounts of $\mathrm{CO}_{2}$ (and related greenhouse gasses) are fundamental aims to reactivate the mitigation idea. Ample opportunities exist among others in the energy sector, which heavily depends on fossil energy sources. A transition to renewable energy sources and technologies is unavoidable and mandatory, but will not lead to sufficient climate stabilization and environmental quality results. Carbon taxes aimed at reducing the consumption of fossil fuel based energy, are often mentioned as complementary measures (see e.g. Carraro, 2012). In 2017, for global policy reasons, this target looks more remote and less credible than ever before. Since the European Commission launched the idea of adopting a policy targeted at limiting the climate change mediated temperature at $2^{\circ} \mathrm{C}$ at most, this became a target for global climate change policy (Delbeke and Vis, 2015). If this target is ex- ceeded, the world could experience the highest ever global SLR in the history of human civilization. Moreover, geoengineering as a technological response is most questionable, not only because of its intrinsic risks but also because doubt exist on whether it can sufficiently reduce the radiative forcing (Jevreja et al., 2017). On increasing temperatures, SLR and the related effects (Jordan et al., 2013).

Most likely however, policy targets need to be changed: taking the uncomfortable step of going beyond the $2^{\circ} \mathrm{C}$ scenario becomes more imperative in a world acting too passively on increasing temperatures, SLR and the related effects (Jordan et al., 2013). However new policy targets can only be realized in a context of sufficient awareness, literacy, capacity, and constructive perception of what is needed.

Adaptation: Adaptation to a new climate situation and its effects became common once it was realized that the climate changes were a fact, and that mitigation alone as an insufficient answer to the problem. The identification of adaptation measures requires an interdisciplinary approach, not only involving scientists but also other societal stakeholders. Ideally adaptation measures should have a noregret character.

Until now technical measures adapting to SLR related effects prevail. Dike levels were increased protecting cities from floods, deforested mangroves were replanted, and people who lost their houses by storms were offered new buildings remote from the sea. Migration away from the lowest areas will be important. SLR in 84 developing coastal countries might displace tens of millions of people within this century (Dasgupta et al., 2009). This is a costly and difficult to implement consequence with a severe risk of social and economic disruption.Therefore changing the prevailing scenarios of protecting the local population from flooding is needed (McGranahan et al., 2007). 


\section{Vietnam Journal of Earth Sciences, 40(2), 126-152}

Not only migration has its back draws. Many replanted mangroves do not show the biodiversity of the original ecosystems. Desalinating groundwater or transporting drinking water over large distances is energy demanding and costly. Moreover, although each of these interventions helps, they are insufficient as a reply to the current trends. Definitively above a certain level of change, adaptation may be unable to keep pace with the rate of change or may only be possible at unacceptable high social and/or environmental costs (Jordan, 2013). This places poverty reduction, risk spreading through income diversification, property management rights, and collective security for the inhabitants of low lying coastal areas as in Vietnam, in the center of the adaptation measures to SLR.

Vulnerability and resilience: Adaptation, vulnerability and resilience are interlinked. Vulnerability is the capacity of individuals to respond to, recover from or adapt to any external stress which is put on their livelihoods and well-being. It is seriously affected by extremes (as hard weather conditions) of the physical environment. But ultimately vulnerability dovetails in human behavior patterns, public policies, and structural constraints of societies. Vulnerability is most obvious in areas with dense populations (Montz et al., 2017).

Resilience is determined by the potential of the threatened populations to reply to external stresses. Adaptation is a measure for increased resilience. As adaptation resilience is interdisciplinary in nature: Resilience combines and integrates economic, environmental, health and social justice aspects. Main instruments to increase the resilience of a vulnerable population include risk assessment and planning.

Risk is often defined as probability multiplied by consequences. The probability refers to a certain flood event and consequence stands for the corresponding (monetary) damage. Risk assessment allows to identify in a quantitative way vulnerable places for SLR, which should be protected to flood effects.

Increasing the resilience of both natural and human dominated ecosystems is complex. Evidently enhancing the resilience of mangroves and coastal wetlands necessitates different measures as agriculture or tourism. Increasing resilience should go beyond technical measures as engineered infrastructures, but should be complemented with measures to regenerate coastal ecosystems, shifting agriculture practices and increasing the resilience of social systems on e.g. guaranteeing the availability of drinking water.

The debate on how urban agglomerations can be made more resilient to flood risks includes a discussion on a diversification, coordination, and alignment of the risk management strategies, including flood risk prevention through proactive spatial planning, flood defense, flood risk mitigation, flood preparation, and flood recovery (Driessen et al., 2016).

Policy: The complex nature of the powerful dimensions of SLR requires debates on a wider conceptual horizon. This entails noregret and economically viable steps of coastal transformation. The effects of dredging always deeper canals guaranteeing the accessibility of inland ports and damming inland rivers on the coast of in particular vulnerable islands should be reconsidered in a context of integrity and intergenerational solidarity (Reise, 2017). The complex nature of increasing resilience necessitates the use of a wide series of complementary policy instruments ranging from technical interventions, over comprehensive and integrated planning and economy regulations to communication and education interventions.

\section{Conclusions}

Climate change associated SLR is real. Consensus figures point to a $3 \mathrm{~mm}$ increase on average worldwide. Vietnam faces slightly higher values and the trend increases. In 
Vietnam the figures should be diversified according to the region.

SLR is related in a multidimensional way to storms and changing precipitation patterns. All three elements contribute to flood risks, of which the hazards increase fast in urban areas, in particular in the deltas and the southern lowlands of the country.

SLR affects coastal erosion, biodiversity and landscape damage along the coasts and the river banks in particular in the deltas.

A complex problem as SLR requires a multidimensional (environmental, technical, social, economic) policy response. The resilience to SLR can be increased both by mitigation of climate change drivers and by adaptation. On these issues countries as Vietnam should go beyond the prevailing technical resources and address the problems in a holistic, interrelated way.

\section{References}

Aerts J.C.J.H., Hassan A., Savenije H.H.G., Khan M.F., 2000. Using GIS tools and rapid assessment techniques for determining salt intrusion: Stream a river basin management instrument.Physics and Chemistry of the Earth, Part B: Hydrology, Oceans and Atmosphere, 25, 265-273. Doi: 10.1016/S14641909(00)00014-9.

Alongi D.M., 2002. Present state and future of the world's mangrove forests. Environmental Conservation, 29, 331-349. Doi: $10.1017 / \mathrm{S} 0376892902000231$

Alongi D.M., 2015. The impact of climate change on mangrove forests. Curr. Clim. Change Rep., 1, 3039. Doi: 10.1007/s404641-015-0002-x.

Anderson F., Al-Thani N., 2016. Effect of sea level rise and groundwater withdrawal on seawater intrusion in the Gulf Coast aquifer: Implications for agriculture. Journal of Geoscience and Environment Protection, 4, 116-124. Doi: 10.4236/gep.2016.44015.

Anguelovski I., Chu E., Carmin J., 2014. Variations in approaches to urban climate adaptation: Experiences and experimentation from the global South. Global Environmental Change, 27, 156-167. Doi: 10.1016/j.gloenvcha.2014.05.010.
Arustienè J., Kriukaitè J., Satkunas J., Gregorauskas M., 2013. Climate change and groundwater - From modelling to some adaptation means in example of Klaipèda region, Lithuania. In: Climate change adaptation in practice. P. Schmidt-Thomé, J. Klein Eds. John Wiley and Sons Ltd., Chichester, UK., 157-169.

Bamber J.L., Aspinall W.P., Cooke R.M., 2016. A commentary on "how to interpret expert judgement assessments of twenty-first century sea-level rise" by Hylke de Vries and Roderik S.W. Van de Wal. Climatic Change, 137, 321-328. Doi: 10.1007/s10584-016-1672-7.

Barnes C., 2014. Coastal population vulnerability to sea level rise and tropical cyclone intensification under global warming. BSc-thesis. Department of Geography, University of Lethbridge, Alberta Canada.

Be T.T., Sinh B.T., Miller F., 2007. Challenges to sustainable development in the Mekong Delta: Regional and national policy issues and research needs. The Sustainable Mekong Research Network, Bangkok, Thailand, 1-210.

Bellard C., Leclerc C., Courchamp F., 2014. Impact of sea level rise on 10 insular biodiversity hotspots. Global Ecology and Biogeography, 23, 203-212. Doi: 10.1111/geb.12093.

Berg H., Söderholm A.E., Sönderström A.S., Nguyen Thanh Tam, 2017. Recognizing wetland ecosystem services for sustainable rice farming in the Mekong delta. Vietnam. Sustainability Science, 12, 137-154. Doi: 10.1007/s11625-016-0409-x.

Bilskie M.V., Hagen S.C., Medeiros S.C., Passeri D.L., 2014. Dynamics of sea level rise and coastal flooding on a changing landscape. Geophysical Research Letters, 41, 927-934. Doi: 10.1002/2013GL058759.

Binh T.N.K.D., Vromant N., Hung N.T., Hens L., Boon E.K., 2005. Land cover changes between 1968 and 2003 in Cai Nuoc, Ca Mau penisula, Vietnam. Environment, Development and Sustainability, 7, 519536. Doi: 10.1007/s10668-004-6001-z.

Blankespoor B., Dasgupta S., Laplante B., 2014. Sealevel rise and coastal wetlands. Ambio, 43, 9961005. Doi: 10.1007/s13280-014-0500-4.

Brockway R., Bowers D., Hoguane A., Dove V., Vassele V., 2006. A note on salt intrusion in funnelshaped estuaries: Application to the Incomati estuary, Mozambique. Estuarine, Coastal and Shelf Science, 66, 1-5. Doi: 10.1016/j.ecss.2005.07.014. 
Vietnam Journal of Earth Sciences, 40(2), 126-152

Cannaby H., Palmer M.D., Howard T., Bricheno L., Calvert D., Krijnen J., Wood R., Tinker J., Bunney C., Harle J., Saulter A., O’Neill C., Bellingham C., Lowe J., 2015. Projected sea level rise and changes in extreme storm surge and wave events during the $21^{\text {st }}$ century in the region of Singapore. Ocean Sci. Discuss, 12, 2955-3001. Doi: 10.5194/osd-12-29552015.

Carraro C., Favero A., Massetti E., 2012. Investment in public finance in a green, low carbon economy. Energy Economics, 34, S15-S18.

Castan-Broto V., Bulkeley H., 2013. A survey ofurban climate change experiments in 100 cities. Global Environmental Change, 23, 92-102. Doi: 10.1016/j.gloenvcha.2012.07.005.

Cazenave A., Le Cozannet G., 2014. Sea level rise and its coastal impacts. GeoHealth, 2, 15-34. Doi: 10.1002/2013EF000188.

Chu M.L., Guzman J.A., Munoz-Carpena R., Kiker G.A., Linkov I., 2014. A simplified approach for simulating changes in beach habitat due to the combined effects of long-term sea level rise, storm erosion and nourishment. Environmental modeling and software, 52, 111-120. Doi.org/10.1016/j.envcsoft.2013.10.020.

Church J.A. et al., 2013. Sea level change. In: Climate change 2013: The physical science basis. Contribution of working group I to the fifth assessment report of Intergovernmental Panel on Climate Change. Eds: Stocker T.F., Qin D., Plattner G.-K., Tignor M., Allen S.K., Boschung J., Nauels A., Xia Y., Bex V., Midgley P.M., Cambridge University Press, Cambridge, UK.

Connell J., 2016. Last days of the Carteret Islands? Climate change, livelihoods and migration on coral atolls. Asia Pacific Viewpoint, 57, 3-15. Doi: 10.1111/apv.12118.

Dasgupta S., Laplante B., Meisner C., Wheeler, Yan J., 2009. The impact of sea level rise on developing countries: A comparative analysis. Climatic Change, 93, 379-388. Doi: 10.1007/s 10584-008-9499-5.

Delbeke J., Vis P., 2015. EU climate policy explained, 136p. Routledge, Oxon, UK.

DiGeorgio M., 2015. Bargaining with disaster: Flooding, climate change, and urban growth ambitions in Quy
Nhon, Vietnam. Public Affairs, 88, 577-597. Doi: 10.5509/2015883577.

Do Minh Duc, Yasuhara K., Nguyen Manh Hieu, 2015. Enhancement of coastal protection under the context of climate change: A case study of Hai Hau coast, Vietnam. Proceedings of the $10^{\text {th }}$ Asian Regional Conference of IAEG, 1-8.

Do Minh Duc, Yasuhara K., Nguyen Manh Hieu, Lan Nguyen Chau, 2017. Climate change impacts on a large-scale erosion coast of Hai Hau district, Vietnam and the adaptation. Journal of Coastal Conservation, 21, 47-62.

Donner S.D., Webber S., 2014. Obstacles to climate change adaptation decisions: A case study of sealevel rise; and coastal protection measures in Kiribati. Sustainability Science, 9, 331-345. Doi: 10.1007/s11625-014-0242-z.

Driessen P.P.J., Hegger D.L.T., Bakker M.H.N., Van Renswick H.F.M.W., Kundzewicz Z.W., 2016. Toward more resilient flood risk governance. Ecology and Society, 21, 53-61. Doi: 10.5751/ES-08921210453.

Duangyiwa C., Yu D., Wilby R., Aobpaet A., 2015. Coastal flood risks in the Bangkok Metropolitan region, Thailand: Combined impacts on land subsidence, sea level rise and storm surge. American Geophysical Union, Fall meeting 2015, abstract\#NH33C-1927.

Duarte C.M., Losada I.J., Hendriks I.E., Mazarrasa I., Marba N., 2013. The role of coastal plant communities for climate change mitigation and adaptation. Nature Climate Change, 3, 961-968. Doi: 10.1038/nclimate1970.

Erban L.E., Gorelick S.M., Zebker H.A., 2014. Groundwater extraction, land subsidence, and sealevel rise in the Mekong Delta, Vietnam. Environmental Research Letters, 9, 1-20. Doi: 10.1088/1748-9326/9/8/084010.

FAO - Food and Agriculture Organisation, 2007.The world's mangroves 1980-2005. FAO Forestry Paper, 153, Rome, Italy.

Farbotko C., 2010. Wishful sinking: Disappearing islands, climate refugees and cosmopolitan experimentation. Asia Pacific Viewpoint, 51, 47-60. Doi: 10.1111/j.1467-8373.2010.001413.x. 
Luc Hens, et al./Vietnam Journal of Earth Sciences 40 (2018)

Goltermann D., Ujeyl G., Pasche E., 2008. Making coastal cities flood resilient in the era of climate change. Proceedings of the $4^{\text {th }}$ International Symposium on flood defense: Managing flood risk, reliability and vulnerability, 148-1-148-11. Toronto, Canada.

Gong W., Shen J., 2011. The response of salt intrusion to changes in river discharge and tidal mixing during the dry season in the Modaomen Estuary, China. Continental Shelf Research, 31, 769-788. Doi: 10.1016/j.csr.2011.01.011.

Gosian L., 2014. Protect the world's deltas. Nature, 516, 31-34.

Graham S., Barnett J., Fincher R., Mortreux C., Hurlimann A., 2015. Towards fair outcomes in adaptation to sea-level rise. Climatic Change, 130, 411-424. Doi: $\quad 10.1007 / \mathrm{s} 10584-014-1171-7 . C O A S T R E S-D-$ 12-00175.1.

Güneralp B., Güneralp I., Liu Y., 2015. Changing global patterns of urban expoàsure to flood and drought hazards. Global Environmental Change, 31, 217 225. Doi: 10.1016/j.gloenvcha.2015.01.002.

Hallegatte S., Green C., Nicholls R.J., Corfee-Morlot J., 2013. Future flood losses in major coastal cities. Nature Climate Change, 3, 802-806. Doi: 10.1038/nclimate1979.

Hamlington B.D., Strassburg M.W., Leben R.R., Han W., Nerem R.S., Kim K.-Y., 2014. Uncovering an anthropogenic sea-level rise signal in the Pacific Ocean. Nature Climate Change, 4, 782-785. Doi: 10.1038/nclimate2307.

Hashimoto T.R., 2001. Environmental issues and recent infrastructure development in the Mekong Delta: Review, analysis and recommendations with particular reference to large-scale water control projects and the development of coastal areas. Working paper series (Working paper No. 4). Australian Mekong Resource Centre, University of Sydney, Australia, 1-70.

Hibbert F.D., Rohling E.J., Dutton A., Williams F.H., Chutcharavan P.M., Zhao C., Tamisiea M.E., 2016. Coral indicators of past sea-level change: A global repository of U-series dated benchmarks. Quaternary Science Reviews, 145, 1-56. Doi: 10.1016/j.quascirev.2016.04.019.
Hinkel J., Lincke D., Vafeidis A., Perrette M., Nicholls R.J., Tol R.S.J., Mazeion B., Fettweis X., Ionescu C., Levermann A., 2014. Coastal flood damage and adaptation costs under $21^{\text {st }}$ century sea-level rise. Proceedings of the National Academy of Sciences, 111, 3292-3297. Doi: 10.1073/pnas.1222469111.

Hinkel J., Nicholls R.J., Tol R.S.J., Wang Z.B., Hamilton J.M., Boot G., Vafeidis A.T., McFadden L., Ganapolski A., Klei R.J.Y., 2013. A global analysis of erosion of sandy beaches and sea level rise: An application of DIVA. Global and Planetary Change, 111, 150-158. Doi: 10.1016/j.gloplacha.2013.09.002.

Huong H.T.L., Pathirana A., 2013. Urbanization and climate change impacts on future urban flooding in Can Tho city, Vietnam. Hydrol. Earth Syst. Sci., 17, 379-394. Doi: 10.5194/hess-17-379-2013.

Hurlimann A., Barnett J., Fincher R., Osbaldiston N., Montreux C., Graham S., 2014. Urban planning and sustainable adaptation to sea-level rise. Landscape and Urban Planning, 126, 84-93. Doi: 10.1016/j.landurbplan.2013.12.013.

IMHEN-Vietnam Institute of Meteorology, Hydrology and Environment, 2011. Climate change vulnerability and risk assessment study for Ca Mau and Kien Giang provinces, Vietnam. Hanoi, Vietnam Institute of Meteorology, Hydrology and Environment (IMHEN), 250p.

IMHEN-Vietnam Institute of Meteorology, Hydrology and Environment, Ca Mau PPC, 2011. Climate change impact and adaptation study in The Mekong Delta - Part A: Ca Mau Atlas. Hanoi, Vietnam: Institute of Meteorology, Hydrology and Environment (IMHEN), 48p.

IPCC-Intergovernmental Panel on Climate Change, 2014. Fifth assessment report. Cambridge University Press, Cambridge, UK.

Jevrejeva S., Jackson L.P., Riva R.E.M., Grinsted A., Moore J.C., 2016. Coastal sea level rise with warming above $2^{\circ} \mathrm{C}$. Proceedings of the National Academy of Sciences, 113, 13342-13347. Doi: 10.1073/pnas.1605312113.

Junk W.J., AN S., Finlayson C.M., Gopal B., Kvet J., Mitchell S.A., Mitsch W.J., Robarts R.D., 2013. Current state of knowledge regarding the world's wetlands and their future under global climate 
Vietnam Journal of Earth Sciences, 40(2), 126-152

change: A synthesis. Aquatic Science, 75, 151-167. Doi: 10.1007/s00027-012-0278-z.

Jordan A., Rayner T., Schroeder H., Adger N., Anderson K., Bows A., Le Quéré C., Joshi M., Mander S., Vaughan N., Whitmarsh L., 2013. Going beyond two degrees? The risks and opportunities of alternative options. Climate Policy, 13, 751-769. Doi: 10.1080/14693062.2013.835705.

Kelly P.M., Adger W.N., 2000. Theory and practice in assessing vulnerability to climate change and facilitating adaptation. Climatic Change, 47, 325-352. Doi: 10.1023/A:1005627828199.

Kirwan M.L., Megonigal J.P., 2013. Tidal wetland stability in the face of human impacts and sea-level rice. Nature, 504, 53-60. Doi: 10.1038/nature 12856.

Koerth J., Vafeidis A.T., Hinkel J., Sterr H., 2013. What motivates coastal households to adapt pro-actively to sea-level rise and increased flood risk? Regional Environmental Change, 13, 879-909. Doi: 10.1007/s10113-12-399-x.

Kontgis K., Schneider A., Fox J;,Saksena S., Spencer J.H., Castrence M., 2014. Monitoring periurbanization in the greater Ho Chi Minh City metropolitan area. Applied Geography, 53, 377-388. Doi: 10.1016/j.apgeogr.2014.06.029.

Kopp R.E., Horton R.M., Little C.M., Mitrovica J.X., Oppenheimer M., Rasmussen D.J., Strauss B.H., Tebaldi C., 2014. Probabilistic $21^{\text {st }}$ and $22^{\text {nd }}$ century sea-level projections at a global network of tide-gauge sites. Earth's Future, 2, 383-406. Doi: 10.1002/2014EF000239.

Kuenzer C., Bluemel A., Gebhardt S., Quoc T., Dech S., 2011. Remote sensing of mangrove ecosystems: A review. Remote Sensing, 3, 878-928. Doi: 10.3390/rs3050878.

Lacerda G.B.M., Silva C., Pimenteira C.A.P., Kopp Jr. R.V., Grumback R., Rosa L.P., de Freitas M.A.V., 2013. Guidelines for the strategic management of flood risks in industrial plant oil in the Brazilian coast: Adaptive measures to the impacts of sea level rise. Mitigation and Adaptation Strategies for Global Change, 19, 104-1062. Doi: 10.1007/s11027-01309459-x.

Lam Dao Nguyen, Pham Van Bach, Nguyen Thanh Minh, Pham Thi Mai Thy, Hoang Phi Hung, 2011. Change detection of land use and river bank in Mekong Delta, Vietnam using time series remotely sensed data. Journal of Resources and Ecology, 2, 370-374. Doi: 10.3969/j.issn.1674764x.2011.04.011.

Lang N.T., Ky B.X., Kobayashi H., Buu B.C., 2004. Development of salt tolerant varieties in the Mekong delta. JIRCAS Project, Can Tho University, Can Tho, Vietnam, 152.

Le Cozannet G., Rohmer J., Cazenave A., Idier D., Van de Wal R., de Winter R., Pedreros R., Balouin Y., Vinchon C., Oliveros C., 2015. Evaluating uncertainties of future marine flooding occurrence as sealevel rises. Environmental Modelling and Software, 73, 44-56. Doi: 10.1016/j.envsoft.2015.07.021.

Le Cozannet G., Manceau J.-C., Rohmer J., 2017. Bounding probabilistic sea-level projections with the framework of the possible theory. Environmental Letters Research, 12, 12-14. Doi.org/10.1088/17489326/aa5528.Chikamoto Y., 2014. Recent Walker circulation strengthening and Pacific cooling amplified by Atlantic warming. Nature Climate Change, 4, 888-892. Doi: 10.1038/nclimate2330.

Lovelock C.E., Cahoon D.R., Friess D.A., Gutenspergen G.R., Krauss K.W., Reef R., Rogers K., Saunders M.L., Sidik F., Swales A., Saintilan N., Le Xuan Tuyen, Tran Triet, 2015. The vulnerability of IndoPacific mangrove forests to sea-level rise. Nature, 526, 559-563. Doi: 10.1038/nature15538.

MA Millennium Ecosystem Assessment, 2005. Ecosystems and human well-being: Current state and trends. Island Press, Washington DC, 266p.

Masterson J.P., Fienen M.N., Thieler E.R., Gesch D.B., Gutierrez B.T., Plant N.G., 2014. Effects of sealevel rise on barrier island groundwater system dynamics - ecohydrological implications. Ecohydrology, 7, 1064-1071. Doi: 10.1002/eco.1442.

McGanahan G., Balk D., Anderson B., 2007. The rising tide: Assessing the risks of climate changes and human settlements in low elevation coastal zones.Environment and urbanization, 19, 17-37. Doi: 10.1177/095624780707960.

McIvor A., Möller I., Spencer T., Spalding M., 2012. Reduction of wind and swell waves by mangroves. The Nature Conservancy and Wetlands International, 1-27.

Merryn T., Pidgeon N., Whitmarsh L., Ballenger R., 2016. Expert judgements of sea-level rise at the local scale. Journal of Risk Research, 19, 664-685. Doi.org/10.1080/13669877.2015.1043568. 
Monioudi I.N., Velegrakis A.F., Chatzipavlis A.E., Rigos A., Karambas T., Vousdoukas M.I., Hasiotis T., Koukourouvli N., Peduzzi P., Manoutsoglou E., Poulos S.E., Collins M.B., 2017. Assessment of island beach erosion due to sea level rise: The case of the Aegean archipelago (Eastern Mediterranean). Nat. Hazards Earth Syst. Sci., 17, 449-466. Doi: 10.5194/nhess-17-449-2017.

MONRE - Ministry of Natural Resources and Environment, 2016. Scenarios of climate change and sea level rise for Vietnam. Publishing House of Environmental Resources and Maps Vietnam, Hanoi, $188 \mathrm{p}$.

Montz B.E., Tobin G.A., Hagelman III R.R., 2017. Natural hazards. Explanation and integration. The Guilford Press, NY, 445p.

Morgan L.K., Werner A.D., 2014. Water intrusion vulnerability for freshwater lenses near islands. Journal of Hydrology, 508, 322-327. Doi: 10.1016/j.jhydrol.2013.11.002.

Muis S., Güneralp B., Jongman B., Aerts J.C.H.J., Ward P.J., 2015. Science of the Total Environment, 538, 445-457. Doi: 10.1016/j.scitotenv.2015.08.068.

Murray N.J., Clemens R.S., Phinn S.R., Possingham H.P., Fuller R.A., 2014. Tracking the rapid loss of tidal wetlands in the Yellow Sea. Frontiers in Ecology and Environment, 12, 267-272. Doi: $10.1890 / 130260$.

Neumann B., Vafeidis A.T., Zimmermann J., Nicholls R.J., 2015a. Future coastal population growth and exposure to sea-level rise and coastal flooding. A global assessment. Plos One, 10, 1-22. Doi: 10.1371/journal.pone.0118571.

Nguyen A. Duoc, Savenije H. H., 2006. Salt intrusion in multi-channel estuaries: a case study in the Mekong Delta, Vietnam. Hydrology and Earth System Sciences Discussions, European Geosciences Union, 10, 743-754. Doi: 10.5194/hess-10-743-2006.

Nguyen An Thinh, Nguyen Ngoc Thanh, Luong Thi Tuyen, Luc Hens, 2017. Tourism and beach erosion: Valuing the damage of beach erosion for tourism in the Hoi An, World Heritage site. Journal of Environment, Development and Sustainability.

Nguyen An Thinh, Luc Hens (Eds.), 2018. Human ecology of climate change associated disasters in
Vietnam: Risks for nature and humans in lowland and upland areas. Springer Verlag, Berlin.

Nguyen An Thinh, Vu Anh Dung, Vu Van Phai, Nguyen Ngoc Thanh, Pham Minh Tam, Nguyen Thi Thuy Hang, Le Trinh Hai, Nguyen Viet Thanh, Hoang Khac Lich, Vu Duc Thanh, Nguyen Song Tung, Luong Thi Tuyen, Trinh Phuong Ngoc, Luc Hens, 2017. Human ecological effects of tropical storms in the coastal area of Ky Anh (Ha Tinh, Vietnam). Environ Dev Sustain, 19, 745-767. Doi: 10.1007/s/10668-016-9761-3.

Nguyen Van Hoang, 2017. Potential for desalinization of brackish groundwater aquifer under a background of rising sea level via salt-intrusion prevention river gates in the coastal area of the Red River delta, Vietnam. Environment, Development and Sustainability.

Nguyen Tho, Vromant N., Nguyen Thanh Hung, Hens L., 2008. Soil salinity and sodicity in a shrimp farming coastal area of the Mekong Delta, Vietnam. Environmental Geology, 54, 1739-1746. Doi: 10.1007/s00254-007-0951-z.

Nguyen Thang T.X., Woodroffe C.D., 2016. Assessing relative vulnerability to sea-level rise in the western part of the Mekong River delta. Sustainability Science, 11, 645-659. Doi: 10.1007/s11625-015-0336-2.

Nicholls N.N., Hoozemans F.M.J., Marchand M., Analyzing flood risk and wetland losses due to the global sea-level rise: Regional and global analyses.Global Environmental Change, 9, S69-S87. Doi: 10.1016/s0959-3780(99)00019-9.

Phan Minh Thu, 2006. Application of remote sensing and GIS tools for recognizing changes of mangrove forests in Ca Mau province. In Proceedings of the International Symposium on Geoinformatics for Spatial Infrastructure Development in Earth and Allied Sciences, Ho Chi Minh City, Vietnam, 9-11 November, 1-17.

Reise K., 2017. Facing the third dimension in coastal flatlands. Global sea level rise and the need for coastal transformations. Gaia, 26, 89-93.

Renaud F.G., Le Thi Thu Huong, Lindener C., Vo Thi Guong, Sebesvari Z., 2015. Resilience and shifts in agro-ecosystems facing increasing sea-level rise and salinity intrusion in Ben Tre province, Mekong 
Vietnam Journal of Earth Sciences, 40(2), 126-152

Delta. Climatic Change, 133, 69-84 Doi: 10.1007/s10584-014-1113-4.

Serra P., Pons X., Sauri D., 2008. Land cover and land use in a Mediterranean landscape. Applied Geography, 28, 189-209.

Shearman P., Bryan J., Walsh J.P., 2013.Trends in deltaic change over three decades in the Asia-Pacific Region. Journal of Coastal Research, 29, 1169-1183. Doi: 10.2112/JCOASTRES-D-12-00120.1.

SIWRR-Southern Institute of Water Resources Research, 2016. Annual Report. Ministry of Agriculture and Rural Development, Ho Chi Minh City, $1-19$.

Slangen A.B.A., Katsman C.A., Van de Wal R.S.W., Vermeersen L.L.A., Riva R.E.M., 2012. Towards regional projections of twenty-first century sea-level change based on IPCC RES scenarios. Climate Dynamics, 38, 1191-1209. Doi: 10.1007/s00382-011$1057-6$.

Spencer T., Schuerch M., Nicholls R.J., Hinkel J., Lincke D., Vafeidis A.T., Reef R., McFadden L., Brown S., 2016. Global coastal wetland change under sea-level rise and related stresses: The DIVA wetland change model. Global and Planetary Change, 139, 15-30. Doi:10.1016/j.gloplacha.2015.12.018.

Stammer D., Cazenave A., Ponte R.M., Tamisiea M.E., 2013. Causes of contemporary regional sea level changes. Annual Review of Marine Science, 5, 2146. Doi: 10.1146/annurev-marine-121211-172406.

Tett P., Mee L., 2015. Scenarios explored with Delphi. In: Coastal zones ecosystems services. Eds., Springer, Berlin, Germany, 127-144.

Tran Hong Hanh, 2017. Land use dynamics, its drivers and consequences in the $\mathrm{Ca}$ Mau province, Mekong delta, Vietnam. PhD dissertation, 191p. VUBPRESS Brussels University Press, ISBN-9789057186226, Brussels, Belgium

Tran Thuc, Nguyen Van Thang, Huynh Thi Lan Huong, Mai Van Khiem, Nguyen Xuan Hien, Doan Ha Phong, 2016. Climate change and sea level rise sce- narios for Vietnam. Ministry of Natural resources and Environment. Hanoi, Vietnam.

Tran Hong Hanh, Tran Thuc, Kervyn M., 2015. Dynamics of land cover/land use changes in the Mekong Delta, 1973-2011: A remote sensing analysis of the Tran Van Thoi District, Ca Mau province, Vietnam. Remote Sensing, 7, 2899-2925. Doi: 10.1007/s00254-007-0951-z

Van Lavieren H., Spalding M., Alongi D., Kainuma M., Clüsener-Godt M., Adeel Z., 2012. Securing the future of Mangroves. The United Nations University, Okinawa, Japan, 53, 1-56.

Water Resources Directorate. Ministry of Agriculture and Rural Development, 2016. Available online: http://www.tongcucthuyloi.gov.vn/Tin-tuc-Sukien/Tin-tuc-su-kien-tonghop/catid/12/item/2670/xam-nhap-man-vung-dongbang-song-cuu-long--2015---2016---han-han-omien-trung--tay-nguyen-va-giai-phap-khac-phuc. Last accessed on: 30/9/2016.

Webster P.J., Holland G.J., Curry J.A., Chang H.-R., 2005. Changes in tropical cyclone number, duration, and intensity in a warming environment. Science, 309, 1844-1846. Doi: 10.1126/science.1116448.

Were K.O., Dick O.B., Singh B.R., 2013. Remotely sensing the spatial and temporal land cover changes in Eastern Mau forest reserve and Lake Nakuru drainage Basin, Kenya. Applied Geography, 41, 75-86.

Williams G.A., Helmuth B., Russel B.D., Dong W.-Y., Thiyagarajan V., Seuront L., 2016. Meeting the climate change challenge: Pressing issues in southern China an SE Asian coastal ecosystems. Regional Studies in Marine Science, 8, 373-381. Doi: 10.1016/j.rsma.2016.07.002.

Woodroffe C.D., Rogers K., McKee K.L., Lovdelock C.E., Mendelssohn I.A., Saintilan N., 2016. Mangrove sedimentation and response to relative sealevel rise. Annual Review of Marine Science, 8, 243-266. Doi: 10.1146/annurev-marine-122414034025 . 